\title{
Growth Inhibition of Gram-Positive and Gram-Negative Bacteria by Zinc Oxide Hedgehog Particles
}

\author{
David Rutherford (D) \\ Jaroslav Jíra' \\ Kateřina Kolářová (D) ${ }^{2}$ \\ Iva Matolínová (iD) ${ }^{3}$ \\ Júlia Mičová (iD ${ }^{4}$ \\ Zdenek Remeš ${ }^{2}$ \\ Bohuslav Rezek (D)
}

'Faculty of Electrical Engineering, Czech Technical University, Prague, Czech Republic; ${ }^{2}$ Author Affiliations Institute of Physics, Czech Academy of Sciences, Prague, Czech Republic; ${ }^{3}$ Faculty of Mathematics and Physics, Charles University, Prague, Czech Republic; ${ }^{4}$ Institute of Chemistry, Slovak Academy of Sciences, Bratislava, Slovak Republic
Correspondence: David Rutherford Faculty of Electrical Engineering, Czech Technical University, Technická 2, Prague, 6. Czech Republic

Tel +420 224352334

Email david.rutherford@fel.cvut.cz
Purpose: Nanomaterials for antimicrobial applications have gained interest in recent years due to the increasing bacteria resistance to conventional antibiotics. Wound sterilization, water treatment and surface decontamination all avail from multifunctional materials that also possess excellent antibacterial properties, eg zinc oxide $(\mathrm{ZnO})$. Here, we assess and compare the effects of synthesized hedgehog-like $\mathrm{ZnO}$ structures and commercial $\mathrm{ZnO}$ particles with and without mixing on the inactivation of bacteria on surfaces and in liquid environments.

Methods: Gram-positive (Staphylococcus aureus) and Gram-negative (Escherichia coli) bacteria in microbial culture medium were added to reverse spin bioreactors that contained different concentrations of each $\mathrm{ZnO}$ type to enable dynamic mixing of the bacteria- $\mathrm{ZnO}$ suspensions. Optical density of the bacteria- $\mathrm{ZnO}$ suspensions was measured in real-time and the number of viable bacteria after $24 \mathrm{~h}$ exposure was determined using standard microbiological techniques. The concentration of zinc ion generated from $\mathrm{ZnO}$ dissolution in different liquid types was estimated from the dynamic interaction exposure. Static antibacterial tests without agitation in liquid media and on agar surface were performed for comparison.

Results: A correlation between increasing $\mathrm{ZnO}$ particle concentration and reduction in viable bacteria was not monotonous. The lowest concentration tested $(10 \mu \mathrm{g} / \mathrm{mL})$ even stimulated bacteria growth. The hedgehog $\mathrm{ZnO}$ was significantly more antibacterial than commercial $\mathrm{ZnO}$ particles at higher concentrations (up to $1000 \mu \mathrm{g} / \mathrm{mL}$ tested), more against E. coli than $S$. aureus. Minimum inhibitory concentration in microwell plates was correlated with those results. No inhibition was detected for any $\mathrm{ZnO}$ type deposited on agar surface. Zinc ion release was greatly suppressed in cultivation media. Scanning electron microscopy images revealed that $\mathrm{ZnO}$ needles can pierce membrane of bacteria whereas the commercial $\mathrm{ZnO}$ nanoparticles rather agglomerate on the cell surface.

Conclusion: The inhibition effects are thus mainly controlled by the interaction dynamics between bacteria and $\mathrm{ZnO}$, where mixing greatly enhances antibacterial efficacy of all $\mathrm{ZnO}$ particles. The efficacy is modulated also by $\mathrm{ZnO}$ particle shapes, where hedgehog $\mathrm{ZnO}$ has superior effect, in particular at lower concentrations. However, at too low concentrations, $\mathrm{ZnO}$ can stimulate bacteria growth and must be thus used with caution.

Keywords: antibacterial, biotechnology, nanomaterials, zinc oxide

\section{Introduction}

Zinc oxide $(\mathrm{ZnO})$ nanoparticles $(\mathrm{NP})$ have shown promise at inactivating bacteria at a time when the number of new antibiotics in development is decreasing and more worryingly there is increasing prevalence of bacteria that are resistant to the antibiotics currently used. ${ }^{1}$ Based on their ability to inactivate bacteria, $\mathrm{ZnO} \mathrm{NP}$ 
have already been successfully incorporated into a number of biomedical applications, such as in water treatment ${ }^{2}$ and wound sterilization. ${ }^{3,4} \mathrm{ZnO} \mathrm{NP}$ mechanism of bacteria inactivation is thought to be an interplay between a number of processes: physical interaction and/or electrostatic attraction of the nanoparticle with the bacteria surface resulting in irreparable damage, ${ }^{5}$ generation of reactive oxygen species (ROS) from the nanoparticle surface interaction with surrounding liquid water due to electron-hole pair formation upon ultraviolet (UV) photon absorption, ${ }^{6}$ and partial dissolution of the nanoparticles in solution releasing zinc ions $\left(\mathrm{Zn}^{2+}\right)$ that diffuse across the cell membrane in high concentrations to disrupt normal cell function and cause damage to intracellular biomolecules. $^{7}$ Each individual process alone has the potential to inactivate bacteria under certain conditions, but often they work in synergy. It is this cumulative effect that is expected to ultimately result in bacteria inactivation. The influence that each process has on the antibacterial mechanism is dependent on the physicochemical properties of the nanoparticles, which can differ greatly depending on the synthesis technique. Multiple characterizations and analyses are often used in attempts to elucidate these properties and understand how exactly they govern the mode of interaction with bacteria.

Small scale synthesis of $\mathrm{ZnO}$ NP with unique physicochemical properties has been reported using a range of different techniques such as microwave heating technology, ${ }^{8}$ atmospheric pressure plasma ${ }^{9}$ and wet chemistry-based methods in bulk liquid like hydrothermal growth method. ${ }^{10}$ Nanoparticles synthesized by wet chemical techniques can produce a wide variety of novel morphologies due to the higher influence on chemical reactions in the synthesis procedure and these morphologically complex structures can enhance photocatalytic and antimicrobial properties. ${ }^{11}$ Morphological dependency of photocatalytic activity was reported for $\mathrm{ZnO}$ NP synthesized via hydrothermal growth method by adjusting different ratios of zinc salt, sodium hydroxide $(\mathrm{NaOH})$ and capping agents or chemicals to achieve the different nanostructures. ${ }^{12}$ Flower-like ZnO NP under UV irradiation had the highest reaction rate and degraded organic dye methylene blue more rapidly than needle or sword-shaped structures. It was attributed to more irregularly scattered surface zinc sites which enhanced the reactivity. Tetra needle-like $\mathrm{ZnO}$ structures were found as the most efficient morphology at degrading sulfamethazine under UV illumination compared to flower-like or spherical nanoparticles. ${ }^{13}$ In another study, also with additional UV irradiation, $\mathrm{ZnO}$ nanostructures in hexagonal disc shapes were found to have greater photocatalytic effect than rodshaped crystals, whereas particle size was less of an influence. ${ }^{14}$

Antibacterial effect of $\mathrm{ZnO}$ is influenced not only by the particle morphology but also by the surface topology and it does not require additional UV illumination. $\mathrm{ZnO}$ nanorods were shown to be more bactericidal than spherical nanoparticles, with many bacteria impaled by the rods when there was dynamic mixing of the bacteria nanoparticle suspension, yet there was no antibacterial effect when the interaction was static. ${ }^{15}$ The same sharp nanorods with tip diameters of less than $10 \mathrm{~nm}$ exerted considerable pressure (up to $10 \mathrm{MPa}$ ) on the outer cell wall of bacteria when continuously mixed in solution. ${ }^{16}$ Elsewhere, $\mathrm{ZnO}$ films composed of nanoscopic needles exhibited greater potential to inhibit bacteria biofilm formation compared to micron-length flakes, ${ }^{17}$ and the surface broadness and protrusion of petals in flower-like formations were considered responsible for the differences observed in the antibacterial effect of $\mathrm{ZnO}$ structures. ${ }^{18}$

$\mathrm{ZnO}$ nanoparticles composed of many individual nanosized needle clusters have been synthesized via the hydrothermal growth technique that have a typical crystal wurtzite structure and high purity. ${ }^{10}$ Particle diameter was estimated from electron micrograph images to be approximately $10 \mu \mathrm{m}$ and the needle-like structures appeared to grow outward from a central nucleation point. Analysis of X-ray photoelectron spectroscopy (XPS) data revealed typical Zn 2p peaks and the observed full width half maximum of these peaks indicated the presence of $\mathrm{Zn}^{2+}$. It has been reported that $\mathrm{ZnO} \mathrm{NP}$ with smaller diameters were more bactericidal than larger particles. The interpretation was that smaller particles transfect through the cell membrane and become internalized more easily than larger particles, as well as that the higher surface area-to-volume ratio could generate more reactive oxygen species. ${ }^{3}$ Based on these prior findings, one can assume that particle shape and size may have a certain positive influence on the antibacterial effect of $\mathrm{ZnO}$, however, this effect is not completely understood due to the complexity of such studies and variety of $\mathrm{ZnO}$ materials employed. Our prior studies have hinted at particle shape and size dependency on the antibacterial effect of $\mathrm{ZnO}$ in microbial growth broth with standard unidirectional orbital rotation shaker ${ }^{19}$ and a concentration dependency for nanosized $\mathrm{ZnO}$ in water with bidirectional reverse spin rotation mixing. ${ }^{20}$ In this study, we thus aim to elucidate the influence of $\mathrm{ZnO}$ particle 
shape, size and concentration on the ability to inhibit growth of bacteria in a range of different environments using synthesized needle-like $\mathrm{ZnO}$ structures and commercial $\mathrm{ZnO}$ particles, without using illumination. We assess the antibacterial efficacy of those $\mathrm{ZnO}$ materials by varying also the $\mathrm{ZnO}$ concentration by characterization under both static and dynamic interaction regimes.

\section{Materials and Methods}

In this section, we describe in detail the different types of $\mathrm{ZnO}$ particles used in this study and the preparation of stock solutions. We also provide information on the bacteria strains used to assess the antibacterial effect of the $\mathrm{ZnO}$ particles and outline the different techniques that were used.

\section{Zinc Oxide Preparation}

Zinc oxide particles with needle-like cluster formations, further referred to as hedgehog $\mathrm{ZnO}(\mathrm{HH})$, were synthesized by the hydrothermal growth technique according to the published protocol including extensive post-synthesis characterization. ${ }^{10}$ Briefly, equimolar aqueous solutions of $25 \mathrm{mM}$ zinc nitrate hexahydrate $\left(\mathrm{Zn}\left(\mathrm{NO}_{3}\right)_{2} \cdot 6 \mathrm{H}_{2} \mathrm{O}\right)$ and hexamethylenetetramine (HMTA) were maintained at $90{ }^{\circ} \mathrm{C}$ for $3 \mathrm{~h}$. Precursor salt residue was removed from the sample by washing 3-times with deionized water followed by centrifugation at $18,000 \mathrm{rpm}$ (RCF: $23542 \mathrm{~g}$ ) for $20 \mathrm{~min}$. Finally, the supernatant was removed, and the remaining material was dried by lyophilization and ready for use in the antibacterial tests. Two commercially available $\mathrm{ZnO}$ particles, $50 \mathrm{~nm}$ nanospheres (NS, Sigma Aldrich, Germany) and $10 \mu \mathrm{m}$ micro-grains (MG, US Research Nanomaterials Inc., Houston, U.S.A.), were also tested for comparison. Stock solutions of $2 \mathrm{mg} / \mathrm{mL}$ and further dilutions thereof were made using deionized water $\left(\mathrm{dH}_{2} \mathrm{O}\right.$, conductivity $<0.5 \mu \mathrm{S} / \mathrm{cm}$, Resta, Czech Republic).

\section{Bacteria Cultures}

Two bacteria strains of differing Gram stain properties (Gram-negative Escherichia coli (E. coli) CCM 3954 and Gram-positive Staphylococcus aureus (S. aureus) CCM 3953) were used to assess the efficacy of antibacterial treatment using the different types of $\mathrm{ZnO}$. Stock cultures were kept at $-20{ }^{\circ} \mathrm{C}$ and a fresh culture was prepared the day before each new experiment. $1 \mathrm{~mL}$ of the stock culture was added to 1 Mueller Hinton (MH, Oxoid, Brno, Czech Republic) agar plate and incubated at $37{ }^{\circ} \mathrm{C}$ overnight. The following day, the growth on the agar surface was removed using sterile loop and added to $5 \mathrm{~mL}$ $\mathrm{MH}$ broth (Oxoid, Brno, Czech Republic) and diluted 1:1000 in MH broth to achieve a McFarland's density of 0.5 (Den 1B Densitometer, BioSan, Riga, Latvia). This value is equivalent to approximately $1 \times 10^{8}$ colony forming units per millilitre $(\mathrm{cfu} / \mathrm{mL})$.

\section{Antibacterial Tests Dynamic Interaction in Liquid}

Dynamic interaction of the $\mathrm{ZnO}$ particles and bacteria in liquid suspensions was characterized by optical density (OD) measurements $(850 \mathrm{~nm})$ in $50 \mathrm{~mL}$ Falcon tubes using bioreactors (RTS-1, BioSan, Riga, Latvia) with a reverse spin technology $(2000 \mathrm{rpm} / \mathrm{s})$ to ensure constant mixing and maximum sample aeration during $\mathrm{ZnO}$ exposure. Each experimental batch consisted of freshly prepared bacteria in culture medium (approximately $1 \times 10^{8}$ $\mathrm{cfu} / \mathrm{mL}$ in $\mathrm{MH}$ broth) divided into 4 samples of equal volumes: 3 different concentrations of one $\mathrm{ZnO}$ type and 1 sample without $\mathrm{ZnO}$ to act as a control (reference). The OD of the incubated $\left(37^{\circ} \mathrm{C}\right.$ suspension was measured every $15 \mathrm{~min}$ for $24 \mathrm{~h}$ to obtain growth curves (ie the change in optical density over time). Peak growth rate, the time at which it was achieved, and the average growth rate over the first $12 \mathrm{~h}$ were derived from the OD measurements. The number of viable bacteria cells after $24 \mathrm{~h}$ was measured from the same suspensions by extracting $1 \mathrm{~mL}$ and performing a 1:10 dilution series using $9 \mathrm{~mL} 0.9 \%$ sodium chloride solution ( $\mathrm{NaCl}$, Penta Chemicals Unlimited, Prague, Czech Republic) and adding $1 \mathrm{~mL}$ to $\mathrm{MH}$ agar plates in duplicates. The inoculum dried at room temperature, then the plates were placed in an incubator $\left(37^{\circ} \mathrm{C}\right.$ and the number of colonies on the agar surface was digitally recorded after $24 \mathrm{~h}$ using an automatic colony counter (Sphereflash, IUL Instruments, Barcelona, Spain). Viable bacteria concentration was calculated by multiplication of the number of colonies detected on the agar surface by the dilution factor (ie the sample from the 1:10 dilution series that was used to inoculate the agar plate), and dividing by the area of the agar plate that was analyzed.

\section{Static Interaction in Liquid and on Surfaces}

For characterizing the bacteria- $\mathrm{ZnO}$ interaction under static conditions, minimum inhibitory concentration (MIC) of the different $\mathrm{ZnO}$ types was determined using a standardized broth dilution protocol in microwell 
plates. ${ }^{21}$ Briefly, $50 \mu \mathrm{L}$ of $1 \times 10^{6} \mathrm{cfu} / \mathrm{mL}$ bacteria in $\mathrm{MH}$ broth was added to the same volume of different concentrations of $\mathrm{ZnO}$ particles so that the final bacteria concentration in the well at the start of the experiment was $5 \times 10^{5}$ $\mathrm{cfu} / \mathrm{mL}$. The microwell plates were then placed in a thermostat set at $37{ }^{\circ} \mathrm{C}$ in the dark without shaking to encourage bacteria growth, and MIC was visually determined after $24 \mathrm{~h}$ from wells that did not contain typical bacteria growth. At $\mathrm{ZnO}$ concentrations greater than 512 $\mu \mathrm{g} / \mathrm{mL}$ some sedimentation was observed ( $\mathrm{ZnO}$ is insoluble in water under normal physiological conditions, ie $\mathrm{pH}$ $7.4,37^{\circ} \mathrm{C}$ ) but it did not resemble typical bacteria growth. This is one advantage of the technique being read manually since automated systems that monitor the optical density in the well might incorrectly register $\mathrm{ZnO}$ sedimentation as growth due to detection of a change in the OD signal.

Static interaction was characterized also on surfaces: $1 \mathrm{~mL}$ of the three different types of $\mathrm{ZnO}$ particles in $\mathrm{dH}_{2}$ $\mathrm{O}$ were spread on $\mathrm{MH}$ agar surfaces in Petri dishes and allowed to dry at room temperature in a laminar flow box before bacteria inoculation. The Petri dishes were $60 \mathrm{~mm}$ in diameter having an agar surface area of $28 \mathrm{~cm}^{2}$. Three $\mathrm{ZnO}$ concentrations were tested $(10,100$ and $1000 \mu \mathrm{g} / \mathrm{mL})$ that correspond to an average $\mathrm{ZnO}$ concentration of 0.35 , 3.5 and $35 \mu \mathrm{g} / \mathrm{cm}^{2}$ (weight divided by area). The agar plates were then placed in an incubator $\left(37^{\circ} \mathrm{C}\right.$ for $18-24$ $\mathrm{h}$ ), and the number of colonies was counted using the automatic colony counter and compared to the number of colonies on pristine agar plates without $\mathrm{ZnO}$.

\section{Material Characterization}

\section{Scanning Electron Microscopy}

The morphology of all $\mathrm{ZnO}$ materials employed in this study as well as their interaction with bacteria, was investigated by field emission scanning electron microscopy (FE-SEM, Mira 3, Tescan, Brno, Czech Republic) using an electron beam energy of $15 \mathrm{keV}$. The top-view images were obtained by an in-beam detector in the secondary electrons mode at a working distance of approximately $2 \mathrm{~mm}$. The $1000 \mu \mathrm{g} / \mathrm{mL}$ bacteria-particle suspension used for the OD measurement and cell viability analysis after $24 \mathrm{~h}$ exposure was also used here for imaging. $1 \mathrm{~mL}$ was extracted, added to $9 \mathrm{~mL} \mathrm{dH}_{2} \mathrm{O}$ and further diluted 1:10 in $\mathrm{dH}_{2} \mathrm{O} .10 \mu \mathrm{L}$ of this diluted solution was drop casted onto a silicon wafer and allowed to dry in air before the SEM measurements. Energy-dispersive X-ray (EDX) spectroscopy was employed to analyze the elemental composition of the different types of $\mathrm{ZnO}$.

\section{Zinc lon Measurement}

The concentration of zinc ions released from $\mathrm{ZnO}$ particles in liquid was measured using a standardized Amplite ${ }^{\mathrm{TM}}$ Colorimetric zinc ion quantitation assay according to the manufacturer's instructions (AAT Bioquest, California, U.S.A.). Briefly, the proprietary compound reacts with zinc ions to generate a reaction product $(1: 1)$ which has a strong absorbance signal and quantification of the reaction product correlates with zinc ion concentration in the sample. $50 \mu \mathrm{L}$ of $1000 \mu \mathrm{g} / \mathrm{mL} \mathrm{ZnO}$ in $\mathrm{dH}_{2} \mathrm{O}$ without bacteria or assay standards were mixed with the same volume of reactant and were incubated at room temperature for $10 \mathrm{~min}$ in the dark before the absorbance was measured using UV-vis spectroscopy.

\section{Statistical Analysis}

One-way analysis of variance (ANOVA) was used to test the significance among differences in the viable bacteria concentrations after $24 \mathrm{~h}$ exposure to different concentrations and types of $\mathrm{ZnO}$ relative to bacteria grown without $\mathrm{ZnO}(\alpha=0.05)$. Differences in bacteria concentrations between the same concentrations of the $\mathrm{ZnO}$ types were also subjected to ANOVA and post hoc two-tailed $t$-test to assess the significance of the differences between groups. Two-tailed t-tests between pairs of $\mathrm{ZnO}$ types were also carried out for zinc ion concentration data as well as the bacteria on agar data.

\section{Results}

\section{Reduction in Viable Cell Concentration}

The numbers of viable bacteria after $24 \mathrm{~h}$ exposure to 3 different concentrations of each type of $\mathrm{ZnO}$ using the reverse spin bioreactors are shown in Figure 1. The antibacterial effect of the different $\mathrm{ZnO}$ types varied according to concentration, morphology and, to a lesser degree, bacteria cell type. In the absence of $\mathrm{ZnO}$, viable bacteria concentration increased between 3-5 orders of magnitude from the initial concentration. Similar concentrations of both bacterial species were reached after exposure to all 3 types of $\mathrm{ZnO}$ at the concentration of $10 \mu \mathrm{g} / \mathrm{mL}$. We noticed a statistically significant increase in viable Grampositive $S$. aureus concentration after exposure to $10 \mu \mathrm{g} /$ $\mathrm{mL}$ hedgehog $(\mathrm{HH}) \mathrm{ZnO}$ of $5 \times 10^{10} \mathrm{cfu} / \mathrm{mL}$ compared to the control $\left(9 \times 10^{9} \mathrm{cfu} / \mathrm{mL}\right)$, whereas a slight decrease was recorded for both nanosphere (NS, $1 \times 10^{10}$ from control 

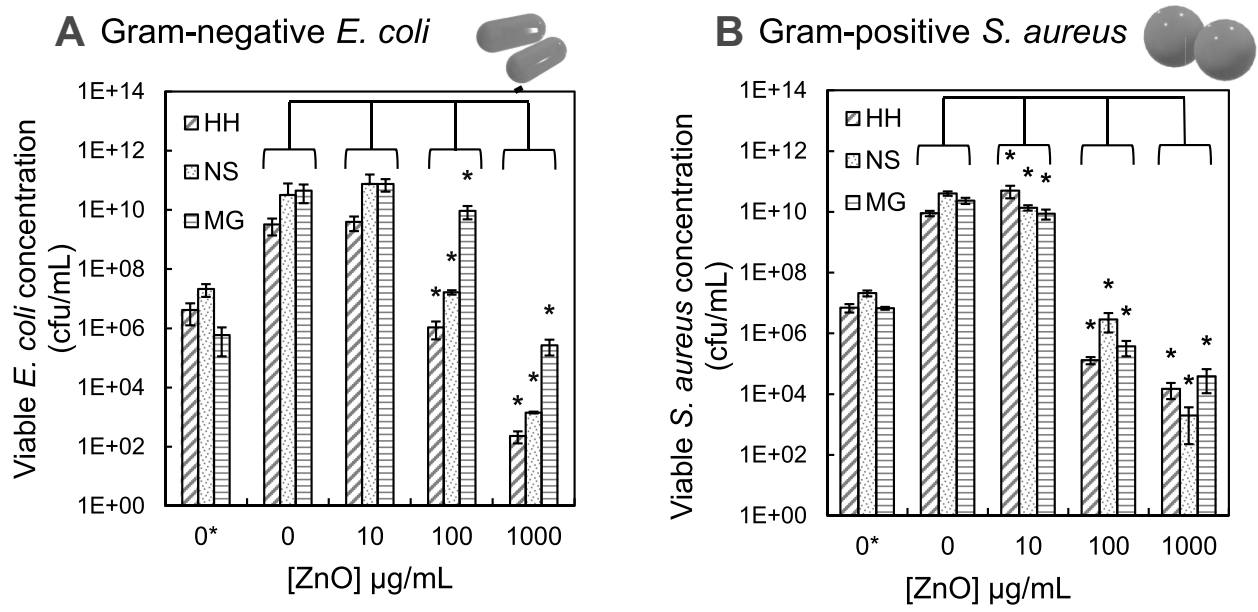

Figure I Viable cell concentration of $E$. coli (A) and S. aureus (B) after $24 \mathrm{~h}$ exposure to different concentrations of $3 \mathrm{ZnO}$ types: $\mathrm{HH}$ (hedgehog), NS (nanospheres) and MG (micrograins). " $0 *$ " is the viable cell concentration at the start of the experiment and ' 0 ' is after 24 hours growth without $\mathrm{ZnO}$. ANOVA analysis between 0 and all $\mathrm{ZnO}$ concentrations $(*=\mathrm{P} \leq 0.05)$.

$\left.4 \times 10^{10} \mathrm{cfu} / \mathrm{mL}\right)$ and micrograin $\left(\mathrm{MG}, 8 \times 10^{9} \mathrm{cfu} / \mathrm{mL}\right.$ from control $2 \times 10^{10} \mathrm{cfu} / \mathrm{mL}$ ) $\mathrm{ZnO}$.

At larger concentrations of all the $\mathrm{ZnO}$ materials (100 $\mu \mathrm{g} / \mathrm{mL}$ and $1000 \mu \mathrm{g} / \mathrm{mL}$ ), the number of viable cells for both bacteria species reduced in a concentration-dependent manner. In Figure 1, one can see that exposure to the highest concentration of hedgehog $\mathrm{ZnO}(1000 \mu \mathrm{g} / \mathrm{mL})$ resulted in a significant 7 orders of magnitude decrease in Gram-negative E. coli concentration relative to the control sample (0), from $3 \times 10^{9} \mathrm{cfu} / \mathrm{mL}$ to $2 \times 10^{2} \mathrm{cfu} / \mathrm{mL}$. There was also a reduction of 4 orders relative to the initial cell concentration $\left(0^{*}\right)$ of $4 \times 10^{6} \mathrm{cfu} / \mathrm{mL}$. Both commercial $\mathrm{ZnO}$ particles were less effective at inhibiting $E$. coli growth at all the concentrations tested, with NS performing better than MG for all concentrations. ANOVA analysis of the E. coli data revealed that the differences relative to the control (0) were not significant for all types of $\mathrm{ZnO}$ at $10 \mu \mathrm{g} / \mathrm{mL}$, whereas the differences were significant for greater concentrations $(100 \mu \mathrm{g} / \mathrm{mL}$ and $1000 \mu \mathrm{g} / \mathrm{mL})$. The situation for $S$. aureus was different and more complex. The largest reduction in viable bacteria relative to the control sample (0) was approx. 7 orders of magnitude using $1000 \mu \mathrm{g} / \mathrm{mL}$ nanospheres $\left(2 \times 10^{3} \mathrm{cfu} / \mathrm{mL}\right)$, followed by 6 orders reduction for the hedgehog $\mathrm{ZnO}\left(1.5 \times 10^{4} \mathrm{cfu} /\right.$ $\mathrm{mL}$ ) then approx. 5.5 ordersreduction for the $\mathrm{ZnO}$ micrograins $\left(4 \times 10^{4} \mathrm{cfu} / \mathrm{mL}\right)$. However, at $100 \mu \mathrm{g} / \mathrm{mL}$ the nanospheres were the least effective at inhibiting $S$. aureus growth achieving approx. 3 orders of magnitude reduction $\left(3 \times 10^{6} \mathrm{cfu} / \mathrm{mL}\right)$ compared to 5.5 orders obtained using the $\mathrm{HH} \mathrm{ZnO}\left(1 \times 10^{5} \mathrm{cfu} / \mathrm{mL}\right)$. Overall, the ANOVA analysis revealed statistically significant reduction in the number of viable E. coli as well as $S$. aureus for all types of $\mathrm{ZnO}$ at $100 \mu \mathrm{g} / \mathrm{mL}$ and $1000 \mu \mathrm{g} / \mathrm{mL}$ relative to the control $(0 \mu \mathrm{g} /$ $\mathrm{mL}$ ). Comparison between the various types of $\mathrm{ZnO}$ revealed that the differences between the synthesized hedgehog $\mathrm{ZnO}$ and both commercial particles were significant. The synthesized $\mathrm{HH} \mathrm{ZnO}$ had a greater antibacterial effect than the commercial particles for Gramnegative $E$. coli. For Gram-positive $S$. aureus, the differences between the $\mathrm{HH} \mathrm{ZnO}$ and commercial particles were not significant, and the antibacterial effect was comparable.

\section{Growth Kinetics}

To complement the above results on bacteria viability we also studied growth kinetics of bacteria exposed to $\mathrm{ZnO}$. The optical density (OD) of the incubated bacteria-particle suspensions was monitored in real time over the 24 $h$ period using the reverse spin bioreactors. It's important to note here that only samples where there was an increase in the number of viable bacteria from the initial cell concentration $\left(0^{*}\right)$ in Figure 1 would produce a measurable increase in OD, ie growth. Figure 2 shows the combined data from all OD measurements for both bacteria species and $\mathrm{ZnO}$ types, where graphs from individual experiments can be viewed in the Supplementary Information (Supplementary Figure S1).

Typical bacteria growth curves have three main phases: lag, exponential and stationary. Lag phase is the initial period before an increase in optical density is detected, and the bacteria are adapting to the new environment. The duration of the lag phase can vary depending on the initial 

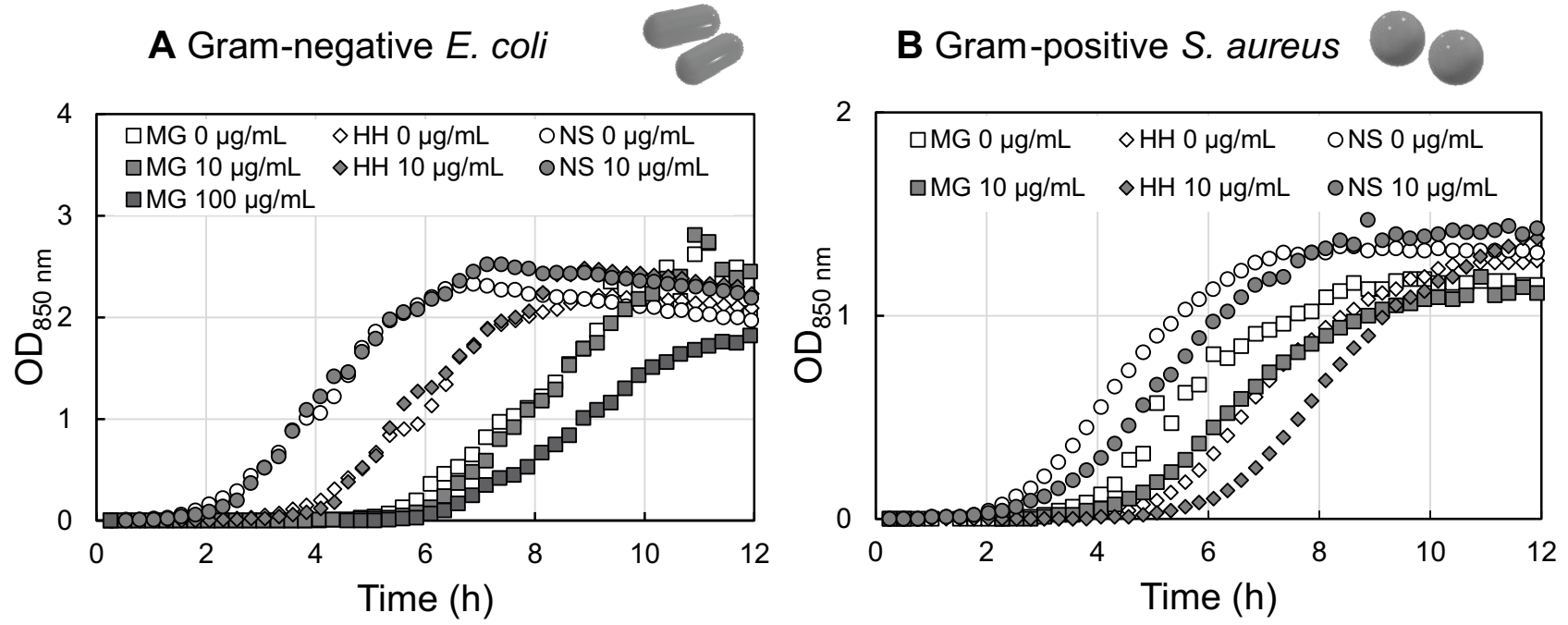

Figure 2 Graphs showing real-time optical density measurements at $850 \mathrm{~nm}$ of the first $12 \mathrm{~h}$ of growth for (A) E. coli and (B) S. aureus exposed to different concentrations of the $3 \mathrm{ZnO}$ types. $0 \mu \mathrm{g} / \mathrm{mL}$ for all $\mathrm{ZnO}$ types is water only.

cell concentration and the degree of damage to bacteria. When bacteria begin to divide, and the number of cells increase, this results in a concurrent increase in the OD of the suspension. Under ample nutrient supply and optimal growth temperature, bacteria are doubling every 30-40 minutes, hence the term "exponential" growth phase. After several hours, nutrients become depleted, and there is no further increase in the OD which is indicative of the final, stationary phase of the growth curve.

Figure $2 \mathrm{~A}$ shows differences in the duration of the lag phase in the control samples $(0 \mu \mathrm{g} / \mathrm{mL})$ that cannot be due to the presence of $\mathrm{ZnO}$, and therefore not due to any $\mathrm{ZnO}$-induced damage of Gram-negative E. coli. The NS $\mathrm{ZnO}$ had the shortest lag phase duration, followed by $\mathrm{HH} \mathrm{ZnO}$, and then $\mathrm{MG} \mathrm{ZnO}$. This can be explained by differences in the initial cell concentrations of each experiment (Figure 1, 0*), where NS had the somewhat bigger number of cells, followed by $\mathrm{HH}$ and $\mathrm{MG}$ had the lowest initial cell concentration. The larger the initial cell concentration, the shorter the lag phase duration. Therefore, it is more appropriate to compare the data from the control $(0 \mu \mathrm{g} / \mathrm{mL})$ and bacteria exposed to $10 \mu \mathrm{g} / \mathrm{mL} \mathrm{ZnO}$ from each experiment separately rather than between $\mathrm{ZnO}$ types. There was less difference in the initial bacteria concentration for the experiments involving S. aureus (Figure 1B), which resulted in similar lag phase durations in Figure 2B. One can see there is little difference in the growth kinetic profiles of bacteria exposed to $10 \mu \mathrm{g} / \mathrm{mL} \mathrm{ZnO}$ compared to unexposed bacteria (ie water only, $0 \mu \mathrm{g} / \mathrm{mL}$ ). This complements the viable bacteria concentration data shown in Figure 1, where the number of bacteria exposed to $10 \mu \mathrm{g} / \mathrm{mL} \mathrm{ZnO}$ was similar to the control (0). For $\mathrm{ZnO}$ concentrations greater than $10 \mu \mathrm{g} / \mathrm{mL}$, only MG at $100 \mu \mathrm{g} / \mathrm{mL}$ generated an increase in OD for E. coli and there was no increase in OD detected using $1000 \mu \mathrm{g} / \mathrm{mL}$ for any $\mathrm{ZnO}$ type (Supplementary Figure S1).

Table 1 summarizes the parameters evaluated from the growth curves. The growth rate was calculated from the difference in OD divided by the difference in time $(\triangle \mathrm{OD} /$ $\Delta t$ ), and the peak growth rate was the largest value in that data set. The time to reach the peak growth rate as well as the average growth rate over the first 12 hours were evaluated from the OD measurements as well.

One can see that there was very little difference in average growth rate within the first $12 \mathrm{~h}$ when bacteria cells were exposed to all $\mathrm{ZnO}$ types at the lowest concentration tested $(10 \mu \mathrm{g} / \mathrm{mL})$ compared to unexposed E. coli and $S$. aureus bacteria (0). This can be clearly seen from the OD measurements in Figure 2, where there is considerable overlap in growth profiles of bacteria exposed to $10 \mu \mathrm{g} / \mathrm{mL} \mathrm{ZnO}$ and unexposed bacteria from the same experiment. The small difference in the average growth rates of exposed and unexposed bacteria could possibly account for the differences in bacteria concentration seen in Figure 1. E. coli concentration after $24 \mathrm{~h}$ growth exposed to $10 \mu \mathrm{g} / \mathrm{mL}$ NS was greater than E. coli concentration not exposed, and from Table 1 we can see that there was a higher average growth rate 
Table I Table Summarizes the Parameters Evaluated from the Growth Curves. The Growth Rate Was Calculated from the Difference in OD Divided by the Difference in Time $(\Delta O D / \Delta t)$, and the Peak Growth Rate Was the Largest Value in That Data Set. The Time Taken to Reach the Peak Growth Rate, as Well as the Average Growth Rate Over the First I2 Hours Were Taken from the OD Measurements

\begin{tabular}{|c|c|c|c|c|c|c|c|}
\hline $\begin{array}{l}\text { E. coli + } \\
\text { ZnO ( } \mu g / \\
\mathrm{mL})\end{array}$ & $\begin{array}{c}\text { Peak } \\
\text { Growth } \\
\text { Rate }\left(\mathrm{h}^{-}{ }^{\prime}\right)\end{array}$ & $\begin{array}{c}\text { Time to Peak } \\
\text { Growth Rate } \\
\text { (h) }\end{array}$ & $\begin{array}{c}\text { Average } \\
\text { Growth Rate } \\
\text { (I2h) }\end{array}$ & $\begin{array}{c}\text { S. aureus + } \\
\mathrm{ZnO}(\mu \mathrm{g} / \\
\mathrm{mL})\end{array}$ & $\begin{array}{c}\text { Peak } \\
\text { Growth } \\
\text { Rate }\left(h^{-1}\right)\end{array}$ & $\begin{array}{c}\text { Time to Peak } \\
\text { Growth Rate } \\
\text { (h) }\end{array}$ & $\begin{array}{c}\text { Average } \\
\text { Growth Rate } \\
\text { (I h) }\end{array}$ \\
\hline $\mathrm{HH}(0)$ & 0.66 & 6.62 & 0.19 & $\mathrm{HH}(0)$ & 0.30 & 7.10 & 0.10 \\
\hline $\mathrm{HH}(10)$ & 0.65 & 5.61 & 0.20 & $\mathrm{HH}(\mathrm{I0})$ & 0.30 & 8.11 & 0.11 \\
\hline $\mathrm{HH}(100)$ & 0 & 0 & 0 & $\mathrm{HH}(100)$ & 0 & 0 & 0 \\
\hline $\mathrm{HH}(1000)$ & 0 & 0 & 0 & $\mathrm{HH}(1000)$ & 0 & 0 & 0 \\
\hline NS (0) & 0.68 & 4.84 & 0.17 & NS (0) & 0.32 & 4.82 & 0.11 \\
\hline NS (I0) & 0.63 & 4.33 & 0.19 & NS (10) & 0.31 & 5.83 & 0.12 \\
\hline NS $(100)$ & 0 & 0 & 0 & NS $(100)$ & 0 & 0 & 0 \\
\hline NS (1000) & 0 & 0 & 0 & NS $(1000)$ & 0 & 0 & 0 \\
\hline MG (0) & 0.57 & 9.13 & 0.20 & MG (0) & 0.24 & 6.85 & 0.10 \\
\hline MG (I0) & 0.58 & 8.63 & 0.21 & MG (I0) & 0.25 & 7.10 & 0.10 \\
\hline MG (100) & 0.43 & 9.83 & 0.14 & MG $(100)$ & 0 & 0 & 0 \\
\hline MG $(1000)$ & 0 & 0 & 0 & MG $(1000)$ & 0 & 0 & 0 \\
\hline
\end{tabular}

over the first $12 \mathrm{~h}$. The same trend applies to $S$. aureus exposed to $10 \mu \mathrm{g} / \mathrm{mL} \mathrm{HH}$; however, it does not apply to all conditions. For example, there was a decrease in S. aureus concentration after exposure to $10 \mu \mathrm{g} / \mathrm{mL} \mathrm{NS}$ but a greater average growth rate was recorded. Only MG at $100 \mu \mathrm{g} / \mathrm{mL}$ failed to inhibit the growth of E. coli but a lower average growth rate and peak growth rate compared to unexposed bacteria was observed. The peak growth rate for $E$. coli in $\mathrm{MH}$ broth was more than double that of $S$. aureus, which can be seen in Figure 2 where OD for E. coli was approximately double that of $S$. aureus irrespective of the presence of $\mathrm{ZnO}$. For both bacteria, it can be seen from Table 1 that exposure to NS $(10 \mu \mathrm{g} / \mathrm{mL})$ resulted in the quickest time to peak growth rate of all $\mathrm{ZnO}$ types $(S$. aureus $=5.83$ and $E$. coli $=$ 4.33 ), and in the case of $E$. coli this was faster than that of unexposed bacteria. This effect was also seen for E. coli exposed to $10 \mu \mathrm{g} / \mathrm{mL} \mathrm{HH}$, and both NS and $\mathrm{HH} 10 \mu \mathrm{g} / \mathrm{mL}$ samples had a higher average growth rate compared to the unexposed (control) bacteria. Interestingly, the lowest peak growth rate for both bacteria strains was recorded using $\mathrm{MG} \mathrm{ZnO}$ yet this did not affect the number of bacteria after $24 \mathrm{~h}$ (Figure 1).

\section{Imaging Bacteria-ZnO interaction}

Scanning electron microscopy was used to visualize the interaction between $\mathrm{ZnO}$ and bacteria after dynamic exposure to $\mathrm{ZnO}$ using the bioreactors. The images can be seen in Figure 3. SEM revealed bacteria as dark shapes in the images alongside the brighter $\mathrm{ZnO}$ particles. The presence of bacteria was confirmed by recognizing the typical shape of the bacteria strains (ie rod shape for E. coli and spherical for $S$. aureus). Figure 3A clearly shows the tip of a needle from $\mathrm{HH} \mathrm{ZnO}$ pierced the outer cell structure of an $E$. coli bacterium, which would result in irreparable membrane damage and cell death. In comparison, nanospheres were found as large agglomerates that encapsulated E. coli (Figure 3B). In contrast, larger $\mathrm{ZnO}$ micrograins were found to have E. coli attached on the surface (Figure 3C). Figure 3E reveals a single $S$. aureus bacterium surrounded by NS and the primary particles agglomerated. We also observed a coating which appeared to cover $\mathrm{HH} \mathrm{ZnO}$ needles as can be seen in Figure 3D. The microbial broth used in this study contains proteins which may absorb onto the surface and promote particle agglomeration, and we can see more than one $\mathrm{HH}$ particle on top 


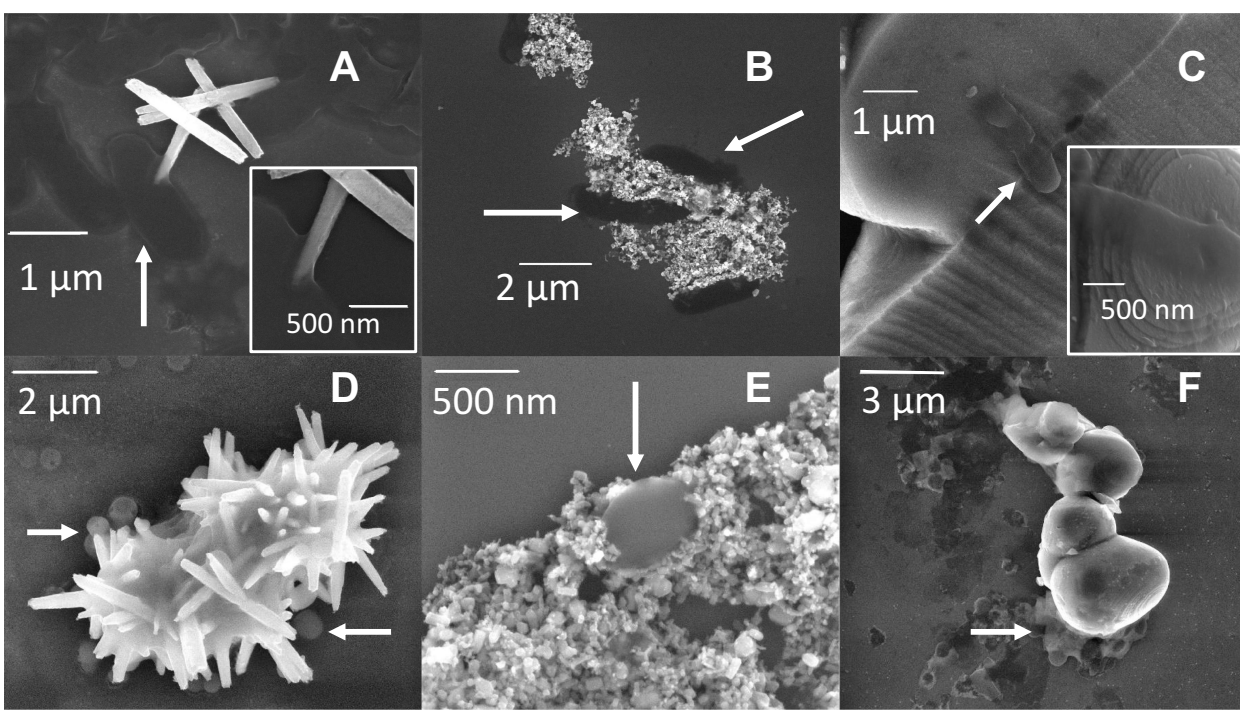

Figure 3 Scanning electron microscopy images showing E. coli (A-C) and S. aureus (D-F) after exposure to $3 \mathrm{ZnO}$ types: hedgehog (HH, (A) and (D), nanospheres (NS, (B) and $(\mathbf{E})$ ) and micrograins (MG, (C) and (F)). All samples were taken directly from $\mathrm{MH}$ broth after $24 \mathrm{~h}$ exposure to $\mathrm{ZnO}(1000 \mu \mathrm{g} / \mathrm{mL})$, diluted in $\mathrm{dH} \mathrm{H}_{2} \mathrm{O} \mathrm{I}: 100 \mathrm{before} \mathrm{drop}$ casting onto silicon substrate for analysis. Inset image in $(\mathbf{A})$ is an enhancement of an area in the same image, whereas the insert image in (C) is taken from a different image to the larger image. Arrows point towards typical-shaped bacteria.

of $S$. aureus cells. These images show that $\mathrm{ZnO}$ of different shapes and sizes have different mechanisms of interaction with bacteria cells. For reference, SEM image of bare $\mathrm{HH} \mathrm{ZnO}$ without bacteria can be seen in Supplementary Information (Supplementary Figure S3).

EDX coupled to SEM was used to probe the elemental composition of the $\mathrm{ZnO}$ materials. All three $\mathrm{ZnO}$ materials had typical peaks for zinc and oxygen from the material and silicon from the substrate (Supplementary Figure S2). There were also carbon and nitrogen peaks in all samples that originated from the bacteria.

\section{Measurement of Zinc lon Release}

It is known that $\mathrm{ZnO}$ NPs undergo partial dissolution when in liquid, releasing $\mathrm{Zn}^{2+}$ into solution that could influence bacteria viability. Therefore, we measured $\mathrm{Zn}^{2+}$ concentration using the same reverse spin bioreactor apparatus that was used for the bacteria experiments. The zinc ion release data were obtained in the absence of bacteria. Figure 4 shows the $\mathrm{Zn}^{2+}$ concentration measured in 2 different liquids (water and $\mathrm{MH}$ broth) immediately and after 24 hours mixing (200 rpm @ RT) for all 3 types of $\mathrm{ZnO}$.

The concentration of $\mathrm{Zn}^{2+}$ measured in water was significantly greater than in the bacteria culture medium (broth) for all the $\mathrm{ZnO}$ types and at both timepoints (Figure 4). In water, the difference in $\mathrm{Zn}^{2+}$ concentration after $24 \mathrm{~h}$ exposure compared to immediate sample removal $(0 \mathrm{~h})$ was not significant for $\mathrm{HH} \mathrm{ZnO}$, unlike for

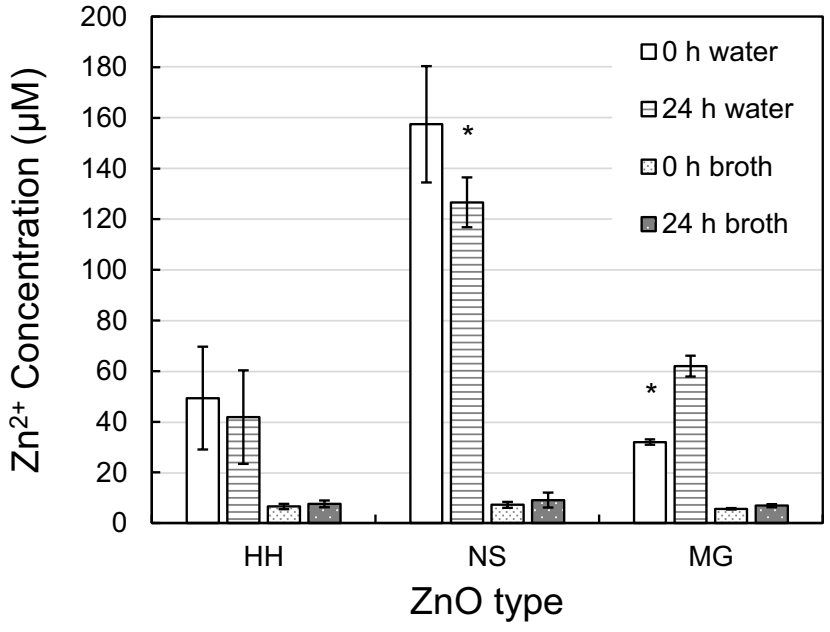

Figure 4 Zinc ion concentration measured from three different $\mathrm{ZnO}$ types in water and Mueller Hinton broth immediately $(0 \mathrm{~h})$ and after $24 \mathrm{~h}$ mixing. Data show an average of 6 measurements. Error bars correspond to the standard deviation of the mean values. ANOVA analysis between 0 and $24 \mathrm{~h}$ is indicated $(*=\mathrm{P}<0.05)$.

NS where a significant decrease was observed and MG produced a significant increase. The largest concentration was recorded from NS in water, and the concentration was higher at the start $(155 \mu \mathrm{M})$ compared to after 24 hours $(125 \mu \mathrm{M})$. A similar trend was observed for $\mathrm{HH}$ in water with $9 \mu \mathrm{M}$ reduction after $24 \mathrm{~h}$, but the opposite occurred for $\mathrm{MG}$ where the $\mathrm{Zn}^{2+}$ concentration almost doubled from $32 \mu \mathrm{M}$ at the start to $61 \mu \mathrm{M}$ after $24 \mathrm{~h} . \mathrm{Zn}^{2+}$ concentration measured in broth at both time points for all $3 \mathrm{ZnO}$ types were not statistically significantly different. The largest $\mathrm{Zn}$ 
ion concentration measured in broth was $8.5 \mu \mathrm{M}$ for nano $\mathrm{ZnO}$ after $24 \mathrm{~h}$ and the lowest was $5.5 \mu \mathrm{M}$ for micron $\mathrm{ZnO}$ at the start of the experiment.

\section{Static Interaction of $\mathrm{ZnO}$ and Bacteria}

The results thus far have shown that exposure to all types of $\mathrm{ZnO}$ influences viable cell concentration and growth kinetics when the bacteria-particle suspension is continually mixed using reverse spin bioreactor apparatus, ie there is a dynamic interaction between bacteria and $\mathrm{ZnO}$. For comparison, we investigated the antibacterial effect of the same $\mathrm{ZnO}$ particles without mixing in liquid and on a surface ie under static interaction. For liquid environment, minimum inhibitory concentrations (MIC) for all $\mathrm{ZnO}$ types using E. coli and S. aureus were estimated following a standardized protocol that is defined as "the lowest concentration of antimicrobial agent that inhibits visible growth of a microorganism".

Figure 5 shows a composite image of microwell plates from the MIC tests. In the microwells containing low concentrations of $\mathrm{ZnO}$, typical bacteria growth was observed as small circular dots at the center of the microwells. As $\mathrm{ZnO}$ concentration increased, the dots disappeared, meaning that

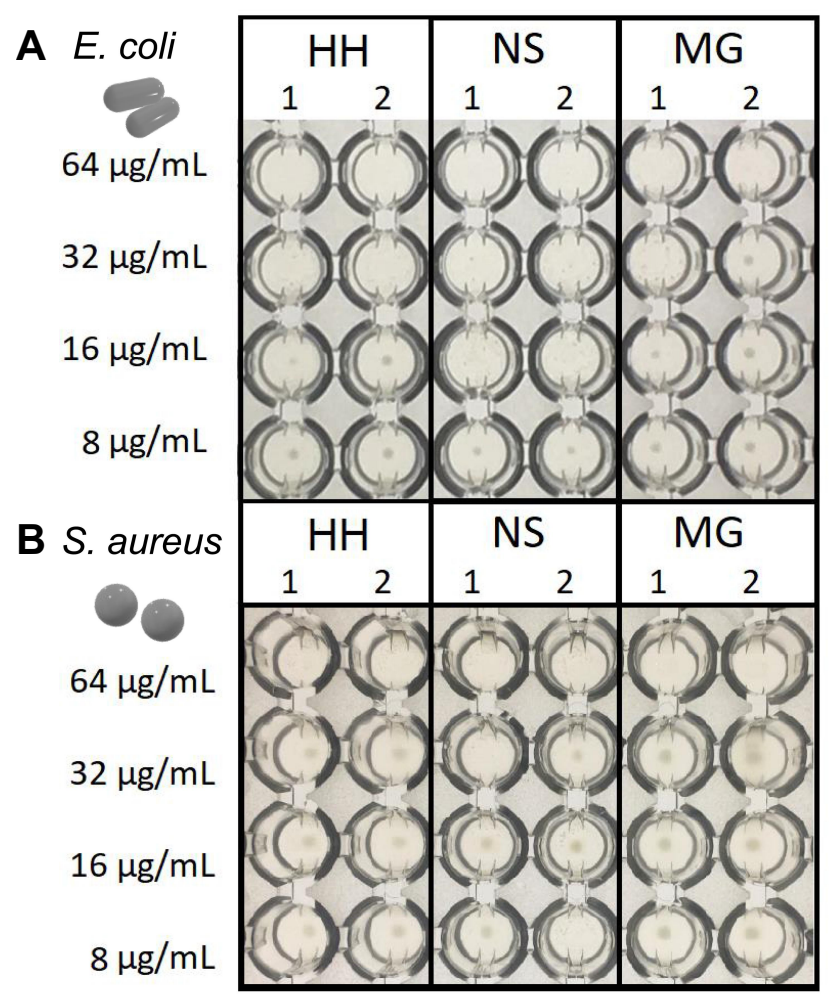

Figure 5 (A) E. coli and (B) S. aureus MIC using 3 different $\mathrm{ZnO}$ types: hedgehog $(\mathrm{HH})$, nanospheres (NS) and micrograins (MG). Concentration of each $\mathrm{ZnO}$ type is stated left of the image. the bacteria growth was inhibited. NS ZnO inhibited E. coli growth at $16 \mu \mathrm{g} / \mathrm{mL}$, whereas $\mathrm{HH} \mathrm{ZnO}$ and $\mathrm{MG} \mathrm{ZnO}$ needed a larger concentration to achieve similar inhibition $(32 \mu \mathrm{g} /$ $\mathrm{mL}$ ). Even larger concentration was required to inhibit Grampositive $S$. aureus $(64 \mu \mathrm{g} / \mathrm{mL})$ for all $\mathrm{ZnO}$ particle types.

In addition to the MIC test, we deposited the 3 types of $\mathrm{ZnO}$ particles from the colloidal solutions in $\mathrm{dH}_{2} \mathrm{O}$ onto a solid growth media ( $\mathrm{MH}$ agar Petri dishes) before the addition of bacteria to test the antibacterial effect of $\mathrm{ZnO}$ on a surface. Figure 6 shows the number of viable bacteria present after $24 \mathrm{~h}$ exposure to $\mathrm{ZnO}$. Statistical analysis between $\mathrm{ZnO}$ types was not possible due to a significant difference in the initial cell concentrations of each of the individual experiments $(\mathrm{p}>0.05)$. Nevertheless, there was no significant differences observed in bacteria cell numbers exposed to all concentrations of $\mathrm{ZnO}$ on agar, even for the highest concentration tested $(1 \mathrm{mg} / \mathrm{mL})$. The same concentration of $\mathrm{ZnO}$ did reduce viable cell concentration in the reverse spin bioreactors (see Figure 1).

\section{Discussion}

There are several extensive review articles that provide an overview of the possible mechanisms involved in antibacterial effects of zinc oxides. ${ }^{11,22-26}$ These mechanisms include the photocatalytic properties of $\mathrm{ZnO}$, reactive oxygen species (ROS) generation, zinc ion toxicity, surface charge, particle shape, particle size and concentration, and the dynamics of the bacteria-material interaction.

Owing to the typical energy band gap of $3.4 \mathrm{eV}$, zinc oxide strongly absorbs ultraviolet (UV) light, and electrons from valence band are excited to the conduction band via photon absorption. The formation of electronhole pairs at the $\mathrm{ZnO}$ surface can lead to interactions with nearby water molecules, initiating a complex cascade of chemical reactions that result in ROS generation. All antibacterial tests in this study were performed indoors under ambient light conditions without UV irradiation. OD measurements and viable bacteria concentrations were obtained from a tube which was completely shielded from light whereas the static interaction antibacterial tests, $\mathrm{MIC}$ and $\mathrm{ZnO}$ on agar, were exposed to indoor light for a short time and then placed inside a thermostat in the dark. Whilst some ROS have been measured in solutions of $\mathrm{ZnO}$ nanoparticles in the dark, ${ }^{27}$ the generated concentrations are too low to cause bacteria inactivation. ${ }^{28}$ Based on these findings, photocatalytic processes cannot be responsible for the observed antibacterial effects in our experiments. 
A Gram-negative E. coli

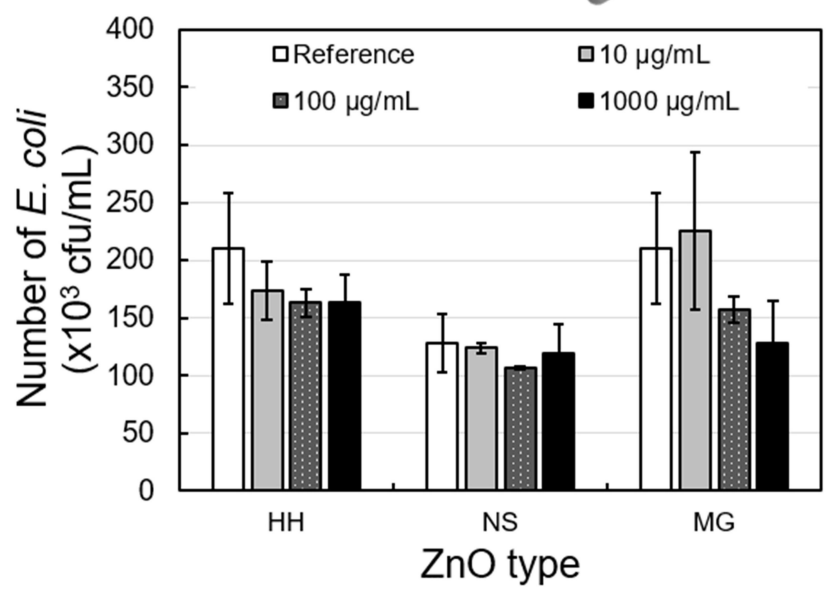

B Gram-positive S. aureus

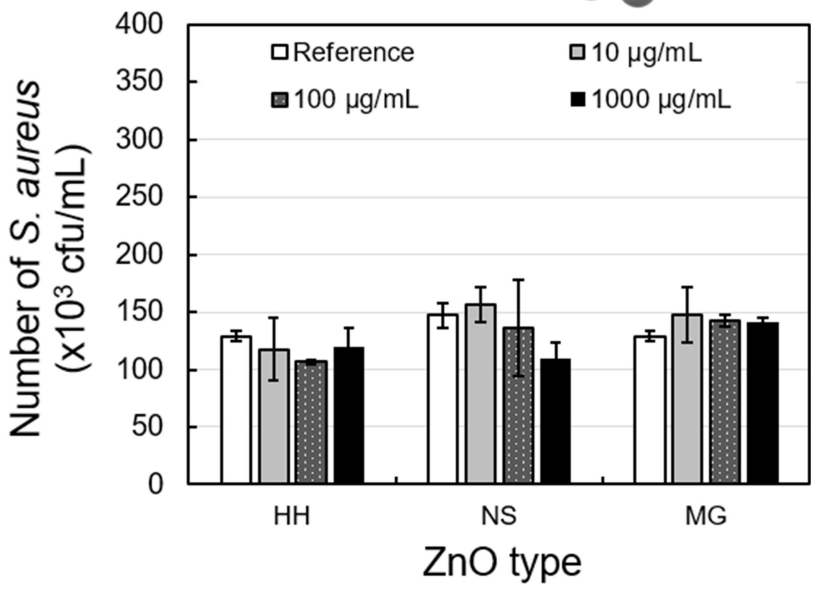

Figure 6 Bar graphs showing the number of (A) E. coli and (B) S. aureus bacteria on an agar surface loaded with different concentrations of 3 types of ZnO: HH, hedgehog; NS, nanospheres and MG, micrograins. Error bars correspond to the standard deviation of the mean ( $P>0.05$ for all).

Zinc ion release from partial dissolution of the nanoparticle in aqueous environment has also been reported to be involved in the antibacterial mechanism. ${ }^{7}$ Bacteria possess homeostasis mechanisms to regulate intracellular zinc ion concentration, ${ }^{29}$ and as a result it requires millimolar concentrations to become toxic to bacteria. ${ }^{30}$ In our experiment, we measured the zinc ion concentration in MH broth well below this range, between 5.5-8.5 $\mu \mathrm{M}$. It has been reported previously that for the highest concentration of $\mathrm{ZnO}$ nanoparticles tested in this study $(1 \mathrm{mg} / \mathrm{mL})$, the concentration of zinc ions produced in bacteria growth medium was $60 \mu \mathrm{g} / \mathrm{mL}^{31}$ and the concentration generated scaled inversely with particle size. ${ }^{32}$ Considering these data, we assume that zinc ions play only a limited role in bacteria inactivation in our experiments.

The electric charge on the surface of $\mathrm{ZnO}$ particles can influence the interaction mechanism with other charged surfaces, such as a bacterial membrane. ${ }^{33}$ The bacterial membrane has a net negative charge on the outside and particles with negatively charged surfaces exhibited lower antibacterial capability than similarly sized positively charged nanoparticles. We confirmed this hypothesis in our prior research, where positively charged hydrogenated nanodiamonds were more bactericidal than negatively charged oxygenated nanodiamonds. ${ }^{34}$ We previously measured the zeta potential of all the $\mathrm{ZnO}$ particles used in this research in $\mathrm{MH}$ broth and we observed negative values ranging from $-17.5 \mathrm{mV}$ for $\mathrm{NS}$ to $-11.7 \mathrm{mV}$ for $\mathrm{HH}^{35} \mathrm{In}$ another of our studies, E. coli zeta potential in Mueller Hinton was measured to be $-8 \mathrm{mV} .{ }^{34}$ Elsewhere, the zeta potential for $S$. aureus in phosphate buffered saline was measured as also negative. ${ }^{33}$ This would make electrostatic attraction between both negatively charged bacteria surfaces and $\mathrm{ZnO}$ surfaces unfavorable and we thus assume that electrostatic interactions are not dominant in the antibacterial mechanism of $\mathrm{ZnO}$ in our system.

The differences in the antibacterial effect of different $\mathrm{ZnO}$ particles in this study may be further explained by the different shape and size of the particles as well as concentration and interaction dynamics. The morphology of the synthesized $\mathrm{ZnO}$ hedgehog particles appears to be the predominant feature that influences how it inactivates bacteria. They are composed of many needle clusters, and we observed from SEM images that some tips of needles had pierced the outer cell wall of bacteria and had become implanted. Analysis of the needle tips showed that in some cases the needle was hollow which would make the walls of the needle incredibly thin and sharp. With a needle puncturing the bacteria cell wall, it would be unlikely that the bacterium remained viable. Generally, SEM images cannot directly distinguish between live and dead bacteria, however analysis of the morphology can yield information on viability. Some bacteria exposed to $\mathrm{ZnO}$ were irregularly shaped with rough, rippled cell wall that are absent in healthy bacteria. Other bacteria observed in SEM could still be viable though. Matula et al have shown than nanorods were more successful at inhibiting E. coli growth than spherical nanoparticles at the highest concentration used in this study $(1000 \mu \mathrm{g} / \mathrm{mL}) .{ }^{15}$ Their electron micrographs of bacteria being impaled by nanorods are remarkably similar to our own images using the $\mathrm{HH}$ particles. The nanorods were created by breaking apart $\mathrm{HH}$ 
$\mathrm{ZnO}$ using sonication prior to antibacterial testing whereas $\mathrm{HH} \mathrm{ZnO}$ used here were single particles with the structure intact. Morphological dependency of the antibacterial effect is also evident for other materials. 1-D arrays of silicon nanosheets displayed excellent anti-biofilm formation, the surface of which was laser ablated to produce a high-aspect-ratio surface topology containing many nanopillars. ${ }^{36}$ A similar surface structure produced from ion beam etching of black silicon also had an antibacterial effect, with SEM images showing the surface was lethal to Gram-positive, Gram-negative and spore forming bacteria. $^{37}$ In both these investigations, the interaction between the antibacterial nanomaterials and cells was static and without mixing whereas the reverse spin technology used here enhances the interaction potential. There are also reports in the literature that show an inverse trend between bactericidal effect and particle size. ${ }^{38,39} \mathrm{We}$ observed this trend for the two types of commercially available $\mathrm{ZnO}$ particles which had uniform particle morphology (spherical nano-sized and grain-like micron-sized $\mathrm{ZnO}$ ). However, as we have shown it is possible that relatively larger particles can be more bactericidal than smaller particles when the morphology of the former is not uniform and has intricate nano-sized needle-like protrusions. In this instance, it is more accurate to refer to the size of the individual nanoneedles that compose the particle and not the particle diameter. Specifically, for particles with extending narrow tips since the tips will interact with the bacteria first.

The concentration range $(10-1000 \mu \mathrm{g} / \mathrm{mL})$ of $\mathrm{ZnO}$ materials tested in this study yielded some interesting microbial responses. The highest concentration tested $(1000 \mu \mathrm{g} / \mathrm{mL})$ resulted in the lowest number of viable cells recorded, and the bactericidal effect lessened as the concentration reduced. Our results agree with other reports in the literature that have also detected a concentrationassociated reduction of viable cells upon exposure to zinc oxide. $^{5,40}$ In fact, for the lowest concentration tested (10 $\mu \mathrm{g} / \mathrm{mL}$ ), we measured a slight increase in average growth rate during the initial 12 hours of growth compared to untreated cells. We previously discussed the potential role of zinc ion in the antibacterial mechanism and concluded its influence would be negligible due to the concentration that would be too low to have a toxic effect. However, zinc ions are also essential for normal cell function. It is thus possible that intracellular metabolic processes are stimulated upon exposure to low concentrations of $\mathrm{ZnO}$ nanoparticles due to the cell detecting a slight increase in zinc ion concentration from the surrounding environment. $^{29}$ The bacteria could then perform zincassociated functions at a faster rate knowing that depleted intracellular zinc ion stores can be replenished from its extracellular surroundings. We measured the number of viable bacteria after 24 hours exposed to $\mathrm{ZnO}$ at optimal growth conditions, and there was indeed a higher number recorded after exposure to the lowest concentration $(10 \mu \mathrm{g} /$ $\mathrm{mL}$ ) than unexposed cells. Brayner et al also reported an increase in the number of viable bacteria grown in the presence of low concentrations of $\mathrm{ZnO}$ and they also suggested increased metabolism as the reason behind these findings. ${ }^{5}$ One-way analysis of variance (ANOVA) was used to test the significance among bacteria exposed to different concentrations of all $\mathrm{ZnO}$ types. For $\alpha=0.05$, the differences between the bacteria concentrations were significant for all $\mathrm{ZnO}$ types against Gram-positive $S$. aureus, and for Gram-negative $E$. coli at higher concentrations $(100 \mu \mathrm{g} / \mathrm{mL}$ and $1000 \mu \mathrm{g} / \mathrm{mL})$. Therefore, we can state that there was a significant increase in $S$. aureus concentration in response to exposure to $10 \mu \mathrm{g} / \mathrm{mL} \mathrm{HH}$, yet a significant decrease in response to $\mathrm{NS}$ and $\mathrm{MG}$ relative to unexposed bacteria at the same concentration. Significant decreases in $S$. aureus bacteria were also observed for higher concentrations $(100 \mu \mathrm{g} / \mathrm{mL}$ and 1000 $\mu \mathrm{g} / \mathrm{mL}$ ) of all $\mathrm{ZnO}$ types. Exposure to $\mathrm{HH}$ and $\mathrm{MG} \mathrm{ZnO}$ resulted in significant decreases in $E$. coli bacteria for the higher concentrations, yet no significant difference was observed for the low concentration $(10 \mu \mathrm{g} / \mathrm{mL})$. Because the differences between control and $10 \mu \mathrm{g} / \mathrm{mL} \mathrm{ZnO}$ for $E$. coli were not statistically significant, we can state that there was no antibacterial effect against this bacteria strain exposed to this concentration. Bacteria can develop resistance to a particular antimicrobial agent when the concentration induces sub-lethal stress and the question remains unanswered whether bacteria can develop resistance towards nanoparticles in the same manner as they have with antibiotics.

Ability of $\mathrm{ZnO}$ nanoparticles to inactivate bacteria, particularly $\mathrm{ZnO}$ with rod-like morphologies or composed of sharp protrusions, relies on the particle having sufficient kinetic energy in order to interact with the bacteria cell with enough force to irreparably damage the outer surface so the bacteria cannot survive. This is routinely achieved in bioreactors by mechanically stirring the liquid containing bacteria and nanoparticles in one direction in order to maximize interaction potential whilst also keeping the insoluble $\mathrm{ZnO}$ in suspension. A variation of this technique, 
called reverse spin (BioSan), rotates a tube which contains the bacteria-nanoparticle suspension for a defined time, then changes the direction of spin and rotates in the opposite direction. This enhances interaction potential whilst also maximizing sample aeration. We used the reverse spin technology to continuously mix the bacteria-nanoparticle suspension because it offered superior dispersal of insoluble material rather than other types of rotation, such as orbital shaking, where $\mathrm{ZnO}$ NP could be pushed outwards due to centrifugal forces and not interact with bacteria. Reverse spin is also less invasive than having a mechanically rotating device inside the suspension or positioned on top of a rotating magnetic element with a small metallic rod in the suspension with the nanoparticles and bacteria. SEM images revealed the reverse spin bioreactor that operated at $2000 \mathrm{rpm} \mathrm{s}^{-1}$ did not damage the needle cluster formations in the absence of bacteria. This ensured that the integrity of the structure remained undamaged due to the force being applied from the bioreactor, and therefore any needles observed in the cell wall of bacteria were a result of direct interaction with a needle cluster.

Minimum inhibitory concentrations (MIC) are often reported in the literature for $\mathrm{ZnO} \mathrm{NP}$ to determine the lowest concentration that can effectively prevent bacteria growth, yet considerable variation in the procedure makes comparison between studies difficult. Differences in the initial bacteria concentration, type of broth used, nanoparticle preparation, and the environment in which the interaction occurs (eg liquid or solid) greatly alters the MIC and introduces unnecessary variation. We chose an established standardized microbiological protocol ${ }^{21}$ to determine the MIC of $\mathrm{ZnO}$ used in our study. We did observe sedimentation using high concentrations (>512 $\mu \mathrm{g} / \mathrm{mL})$. Nevertheless, it did not obstruct identification of typical bacteria growth in the centers of microwells and we obtained MIC values within a lower, narrow range of 16-64 $\mu \mathrm{g} / \mathrm{mL}$.

The lowest MIC against Gram-negative E. coli was 16 $\mu \mathrm{g} / \mathrm{mL}$ of $\mathrm{NS} \mathrm{ZnO}$, followed by $32 \mu \mathrm{g} / \mathrm{mL}$ of $\mathrm{HH} \mathrm{ZnO}$ and 32-64 $\mu \mathrm{g} / \mathrm{mL}$ of $\mathrm{MG} \mathrm{ZnO}$. These differences could be due to the insolubility of $\mathrm{ZnO}$ and the static interaction environment, where the larger material settled on the base of the microwells faster than bacteria would, thus creating an unfavorable surface for colonization and inhibit growth here. $\mathrm{HH} \mathrm{ZnO}$ or $\mathrm{MG} \mathrm{ZnO}$ particles would prevent bacteria at the base of the well without necessarily interacting with the bacteria in the liquid volume before sedimentation. The $\mathrm{HH} \mathrm{ZnO}$ with sharp needles are then more effective against settling bacteria than rounded $\mathrm{MG}$ $\mathrm{ZnO}$. However, without mechanical agitation, the $\mathrm{HH} \mathrm{ZnO}$ are less effective than NS $\mathrm{ZnO}$. This is most likely because the small NS $\mathrm{ZnO}$ would remain suspended in solution for a longer period of time and thus probably induce an antibacterial effect through encapsulation (as indicated by the SEM image in Figure 3b). Contrary, MIC for all the $\mathrm{ZnO}$ particles against Gram-positive $S$. aureus were larger, indicating the bacteria was less sensitive towards $\mathrm{ZnO}$ exposure than Gram-negative E. coli. This is in a very good agreement with the result of dynamic experiments (Figure 1b).

The different effect of $\mathrm{ZnO}$ particle sizes and morphologies on the growth inhibition of Gram-positive and Gram-negative bacteria was thus confirmed in two different interaction regimes in liquid: static and dynamic. SEM images from dynamic interaction revealed intimate contact between all $\mathrm{ZnO}$ types, and we assume that the contact has already been initiated prior to drop casting onto silicon. However, we did not observe inhibition when $\mathrm{ZnO}$ was added to agar surface before bacteria inoculation even for the highest concentration tested (Figures 4, $1 \mathrm{mg} / \mathrm{mL}$ ). The most obvious difference between these data in Figure 4 and the results in Figure 1 (where inhibition was achieved) is the interaction kinetics between $\mathrm{ZnO}$ and bacteria that is completely lacking here.

\section{Conclusion}

In this work we assessed and compared the antibacterial mechanisms of synthesized needle-like clusters of $\mathrm{ZnO}$ (resembling hedgehogs) and commercial $\mathrm{ZnO}$ particles in cell culture broth and on agar surfaces using various concentrations and various conditions. No inhibition of bacteria growth was observed on agar surfaces for all the types of tested $\mathrm{ZnO}$ particles. Growth inhibition was controlled mainly by the interaction dynamics between bacteria and $\mathrm{ZnO}$ in liquid. In particular, continuous agitation (mixing) in reverse spin bioreactors greatly enhanced the antibacterial efficacy of all the $\mathrm{ZnO}$ particles. Moreover, the hedgehog $\mathrm{ZnO}$ particles had significantly greater antibacterial effect than commercial $\mathrm{ZnO}$ particles. The difference was more pronounced against Gram-negative E. coli than against Gram-positive $S$. aureus. SEM images revealed that the needle-like structures in the hedgehog $\mathrm{ZnO}$ particles facilitated mechanical damage of bacteria cells. They tend to pierce the membrane of bacteria, which seems more effective against larger oval-shaped E. coli 
than against smaller spherical S. aureus. $\mathrm{ZnO}$ nanospheres rather envelope the bacteria and $\mathrm{ZnO}$ micrograins have bacteria cracked on their surface. The efficacy is thus modulated also by $\mathrm{ZnO}$ particle shapes, in particular at lower concentrations. There is thus a potential for hedgehog $\mathrm{ZnO}$ in water treatment systems that already utilize some agitation to ensure adequate mixing of the water and antibacterial agents to enhance the disinfection efficiency even at lower amounts of $\mathrm{ZnO}$. However, at too low concentrations $(10 \mu \mathrm{g} / \mathrm{mL}), \mathrm{ZnO}$ is not effective or it can even stimulate bacteria growth. Therefore, the optimal $\mathrm{ZnO}$ concentration must be thus adjusted with caution, considering specific application.

\section{Abbreviations}

$\mathrm{ZnO}$, zinc oxide; NP, nanoparticles; ROS, reactive oxygen species; UV, ultraviolet; $\mathrm{NaOH}$, sodium hydroxide; XPS, X-ray photoelectron spectroscopy; E. coli, Escherichia coli; S. aureus, Staphylococcus aureus; HH, hedgehog; $\mathrm{NS}$, nanospheres; $\mathrm{MG}$, micrograins; $\mathrm{dH}_{2} \mathrm{O}$, deionized water; $\mathrm{MH}$, Mueller Hinton; OD, optical density; $\mathrm{NaCl}$, sodium chloride; MIC, minimum inhibitory concentration; FE-SEM, field-emission scanning electron microscope; EDX, energy-dispersive X-ray spectroscopy; ANOVA, One-way analysis of variance.

\section{Acknowledgments}

This research work was financially supported by the project GACR 19-02858J along with our collaborators from National Pingtung University, Pingtung City, Taiwan. We also acknowledge support from MEYS CR under the project CZ.02.1.01/0.0/0.0/16_019/0000778 (CAAS), the Scientific Grant Agency of Ministry of Education, Science, Research and Sport of Slovak Republic and Slovak Academy of Sciences (VEGA 2/0157/20), and the use of CzechNanoLab Research Infrastructure (LM2018110).

\section{Disclosure}

Dr Júlia Mičová reports grants from Scientific Grant Agency of Ministry of Education, Science, Research and Sport of Slovak Republic and Slovak Academy of Sciences, during the conduct of the study. Professor Bohuslav Rezek reports grants from Czech Science Foundation and Ministry of Education, Youth and Sports of the Czech Republic, during the conduct of the study. The authors report no other conflicts of interest in this work.

\section{References}

1. (EFSA) EFSA, (ECDPC) EC for DP and C. The European Union summary report on antimicrobial resistance in zoonotic and indicator bacteria from humans, animals and food in 2017. EFSA Journal. 2019;17(2). doi:10.2903/j.efsa.2019.5598

2. Murcia JJ, Hernández JS, Rojas $\mathrm{H}$, et al. Evaluation of $\mathrm{Au}-\mathrm{ZnO}$, $\mathrm{ZnO} / \mathrm{Ag} 2 \mathrm{CO} 3$ and $\mathrm{Ag}-\mathrm{TiO} 2$ as Photocatalyst for Wastewater Treatment. Top Catal. 2020;63(11):1286-1301. doi:10.1007/s11244020-01232-Z

3. Kaushik M, Niranjan R, Thangam R, et al. Investigations on the antimicrobial activity and wound healing potential of $\mathrm{ZnO}$ nanoparticles. Appl Surf Sci. 2019;479:1169-1177. doi:10.1016/j. apsusc.2019.02.189

4. Cleetus CM, Primo FA, Fregoso G, et al. Alginate Hydrogels with Embedded $\mathrm{ZnO}$ Nanoparticles for Wound Healing Therapy. Int J Nanomedicine. 2020;15:5097-5111. doi:10.2147/IJN.S255937

5. Brayner R, Ferrari-Iliou R, Brivois N, Djediat S, Benedetti MF, Toxicological Impact FF. Studies Based on Escherichia coli Bacteria in Ultrafine ZnO Nanoparticles Colloidal Medium. Nano Lett. 2006;6(4):866-870. doi:10.1021/n1052326h

6. Dwivedi S, Wahab R, Khan F, Mishra YK, Musarrat J, Al-Khedhairy AA. Reactive Oxygen Species Mediated Bacterial Biofilm Inhibition via Zinc Oxide Nanoparticles and Their Statistical Determination. PLoS One. 2014;9(11):e111289. doi:10.1371/journal.pone.0111289

7. Pasquet J, Chevalier Y, Pelletier J, Couval E, Bouvier D, Bolzinger M-A. The contribution of zinc ions to the antimicrobial activity of zinc oxide. Colloids Surf a Physicochem Eng Asp. 2014;457:263-274. doi:10.1016/j.colsurfa.2014.05.057

8. Wojnarowicz J, Chudoba T, Lojkowski WA. Review of Microwave Synthesis of Zinc Oxide Nanomaterials: reactants, Process Parameters and Morphologies. Nanomaterials. 2020;10(6):1086. doi:10.3390/nano10061086

9. Jain G, Macias-Montero M, Velusamy T, Maguire P, Mariotti D. Porous zinc oxide nanocrystalline film deposition by atmospheric pressure plasma: fabrication and energy band estimation. Plasma Process Polym. 2017;14(12):1700052. doi:10.1002/ppap.201700052

10. Mičová J, Buryi M, Šimek D, et al. Synthesis of zinc oxide nanostructures and comparison of their crystal quality. Appl Surf Sci. 2018;461:190-195. doi:10.1016/j.apsusc.2018.05.176

11. Sheikh M, Pazirofteh M, Dehghani M, et al. Application of $\mathrm{ZnO}$ nanostructures in ceramic and polymeric membranes for water and wastewater technologies: a review. Chem Eng J. 2020;391:123475. doi:10.1016/j.cej.2019.123475

12. Wang X, Zhang Q, Wan Q, Dai G, Zhou C, Zou B. Controllable ZnO Architectures by Ethanolamine-Assisted Hydrothermal Reaction for Enhanced Photocatalytic Activity. J Phys Chem C. 2011;115 (6):2769-2775. doi:10.1021/jp1096822

13. Yi Z, Wang J, Jiang T, Tang Q, Cheng Y. Photocatalytic degradation of sulfamethazine in aqueous solution using $\mathrm{ZnO}$ with different morphologies. Royal Soc Open Sci. 2018;5(4):171457. doi:10.1098/ rsos. 171457

14. Mclaren A, Valdes-Solis T, Li G, Tsang SC. Shape and Size Effects of $\mathrm{ZnO}$ Nanocrystals on Photocatalytic Activity. J Am Chem Soc. 2009;131(35):12540-12541. doi:10.1021/ja9052703

15. Matuła K, Ł R, Adamkiewicz W, Åkerström B, Paczesny J, Hołyst R. Influence of nanomechanical stress induced by $\mathrm{ZnO}$ nanoparticles of different shapes on the viability of cells. Soft Matter. 2016;12 (18):4162-4169. doi:10.1039/C6SM00336B

16. Matuła K, Ł R, Janczuk-Richter M, et al. Phenotypic plasticity of Escherichia coli upon exposure to physical stress induced by $\mathrm{ZnO}$ nanorods. Sci Rep. 2019;9(1):8575. doi:10.1038/s41598-01944727-w

17. Dai Y, Sun T, Zhang Z, Zhang ZJ, Li J. Effect of zinc oxide film morphologies on the formation of Shewanella putrefaciens biofilm. Biointerphases. 2017;12(1):011002. doi:10.1116/1.4976003 
18. Cai Q, Gao Y, Gao T, et al. Insight into Biological Effects of Zinc Oxide Nanoflowers on Bacteria: why Morphology Matters. ACS Appl Mater Interfaces. 2016;8(16):10109-10120. doi:10.1021/acsami.5b11 573

19. Rutherford D, Jíra J, Mičová J, Remeš Z, Shu Hsu H, Rezek B. Comparison of microbial interactions of zinc oxide nanomaterials in various size and shape. Proc Int Conf Nanocon. 2020;330-335. doi:10.37904/nanocon.2019.8666

20. Rutherford D, Jíra J, Kolářová K, Remeš Z, Rezek B. Bactericidal effect of zinc oxide nanoparticles on Gram-positive and Gram-negative strains in reverse spin bioreactor. IOP Conf Ser: Mater Sci Eng. 2021;1050:012013. doi:10.1088/1757-899X/1050/1/ 012013

21. EUCAST. EUCAST reading guide for broth microdilution; 2019. Available from: http:/www.eucast.org/fileadmin/src/media/PDFs/ EUCAST_files/Disk_test_documents/2019_manuals/Reading_guide_ BMD_v_1.0_2019.pdf. Accessed April 30, 2019.

22. Sirelkhatim A, Seeni A, Mohamad D, et al. Review on Zinc Oxide Nanoparticles: antibacterial Activity and Toxicity Mechanism. $\mathrm{nml}$. 2015;7(3):219-242. doi:10.1007/s40820-015-0040-x

23. Dimapilis EAS, Hsu C-S, Mendoza RMO, Lu M-C. Zinc oxide nanoparticles for water disinfection. Sustainable Environ Res. 2018;28(2):47-56. doi:10.1016/j.serj.2017.10.001

24. Siddiqi KS, Rahman A, Tajuddin HA. Properties of Zinc Oxide Nanoparticles and Their Activity Against Microbes. Nanoscale Res Lett. 2018;13(1):141. doi:10.1186/s11671-018-2532-3

25. Mahamuni-Badiger PP, Patil PM, Badiger MV, et al. Biofilm formation to inhibition: role of zinc oxide-based nanoparticles. Materi Sci Eng. 2020;108:110319. doi:10.1016/j.msec.2019.110319

26. Silva BL, Abuçafy MP, Manaia EB, et al. Relationship Between Structure And Antimicrobial Activity Of Zinc Oxide Nanoparticles: an Overview. Int J Nanomedicine. 2017;12:4991-5011. doi:10.2147/ IJN.S216204

27. Lakshmi Prasanna V, Vijayaraghavan R. Insight into the Mechanism of Antibacterial Activity of $\mathrm{ZnO}$ : surface Defects Mediated Reactive Oxygen Species Even in the Dark. Langmuir. 2015;31 (33):9155-9162. doi:10.1021/acs.langmuir.5b02266

28. Rago I, Chandraiahgari CR, Bracciale MP, et al. Zinc oxide microrods and nanorods: different antibacterial activity and their mode of action against Gram-positive bacteria. RSC Adv. 2014;4 (99):56031-56040. doi:10.1039/C4RA08462D

29. Suryawati B. Zinc homeostasis mechanism and its role in bacterial virulence capacity. AIP Conf Proc. 2018;2021(1):070021. doi:10.1063/1.5062819
30. Babich H, Stotzky G. Toxicity of zinc to fungi, bacteria, and coliphages: influence of chloride ions. Appl Environ Microbiol. 1978;36 (6):906-914. doi:10.1128/AEM.36.6.906-914.1978

31. Li M, Zhu L, Lin D. Toxicity of ZnO Nanoparticles to Escherichia coli: mechanism and the Influence of Medium Components. Environ Sci Technol. 2011;45(5):1977-1983. doi:10.1021/es102624t

32. Mudunkotuwa IA, Rupasinghe T, Wu C-M, Grassian VH. Dissolution of $\mathrm{ZnO}$ Nanoparticles at Circumneutral pH: a Study of Size Effects in the Presence and Absence of Citric Acid. Langmuir. 2012;28 (1):396-403. doi:10.1021/la203542x

33. Arakha M, Saleem M, Mallick BC, Jha S. The effects of interfacial potential on antimicrobial propensity of $\mathrm{ZnO}$ nanoparticle. Sci Rep. 2015;5(1):9578. doi:10.1038/srep09578

34. Jira J, Rezek B, Kriha V, et al. Inhibition of E. coli Growth by Nanodiamond and Graphene Oxide Enhanced by Luria-Bertani Medium. Nanomaterials. 2018;8(3):140. doi:10.3390/nano8030140

35. Jíra J, Rutherford DCE, Mičová J, Remeš Z, Rezek B Effect of ZnO nanoparticle sizes and illumination on growth inhibition of Escherichia coli and Staphylococcus aureus bacteria in cultivation medium. IOP Conference Series: Materials Science and Engineering. IoP; 2021.

36. Kudryashov SI, Nguyen LV, Kirilenko DA, et al. Large-scale laser fabrication of antifouling silicon-surface nanosheet arrays via nanoplasmonic ablative self-organization in liquid CS2 Tracked by a Sulfur Dopant. ACS Appl Nano Mater. 2018;1(6):2461-2468. doi:10.1021/acsanm.8b00392

37. Ivanova EP, Hasan J, Webb HK, et al. Bactericidal activity of black silicon. Nat Commun. 2013;4(1):2838. doi:10.1038/ncomms3838

38. Padmavathy N, Vijayaraghavan R. Enhanced bioactivity of $\mathrm{ZnO}$ nanoparticles - an antimicrobial study. Sci Technol Adv Mater. 2008;9(3):3. doi:10.1088/1468-6996/9/3/035004

39. Duffy LL, Osmond-McLeod MJ, Judy J, King T. Investigation into the antibacterial activity of silver, zinc oxide and copper oxide nanoparticles against poultry-relevant isolates of Salmonella and Campylobacter. Food Control. 2018;92:293-300. doi:10.1016/j. foodcont.2018.05.008

40. Reddy KM, Feris K, Bell J, Wingett DG, Hanley C, Punnoose A. Selective toxicity of zinc oxide nanoparticles to prokaryotic and eukaryotic systems. Appl Phys Lett. 2007;90(21):213902. doi:10.1063/1.2742324
International Journal of Nanomedicine

\section{Publish your work in this journal}

The International Journal of Nanomedicine is an international, peerreviewed journal focusing on the application of nanotechnology in diagnostics, therapeutics, and drug delivery systems throughout the biomedical field. This journal is indexed on PubMed Central, MedLine, CAS, SciSearch ${ }^{\mathbb{R}}$, Current Contents ${ }^{\mathbb{R}} /$ Clinical Medicine, $^{2}$

\section{Dovepress}

Journal Citation Reports/Science Edition, EMBase, Scopus and the Elsevier Bibliographic databases. The manuscript management system is completely online and includes a very quick and fair peer-review system, which is all easy to use. Visit http://www.dovepress.com/ testimonials.php to read real quotes from published authors. 